\title{
JAMUR ENDOFIT DARI UMBI BAWANG DAYAK (Eleutherine palmifolia Merr.)
}

\author{
Vendryca Reckow*, Wahyu Widayat, Laode Rijai \\ Laboratorium Penelitian dan Pengembangan "FARMAKA TROPIS" Fakultas Farmasi \\ Universitas Mulawarman, Samarinda, Kalimantan Timur \\ Email: vendryca.permana@gmail.com
}

\begin{abstract}
Bawang Dayak (Eleutherine palmifolia Merr.) Is one of the endemic plants of Borneo, which empirically part of the tuber has been used in the treatment of degenerative. Endophytic fungi be able to produce secondary metabolites. Endophytic fungus live on the leaves, stems or roots of plants. The purpose of this research is to isolate endophytic fungi found in bulbs of bawang dayak and knowing its characteristics microscopically and macroscopically. Isolation of endophytic fungi conducted on Yeast Extract Agar (YEA) and Malt Extract Agar (MEA) medium with surface sterilization techniques using alcohol $70 \%$ and $1 \% \mathrm{NaOCl}$. The result of the isolation of endophytic fungi on MEA medium 1 isolates obtained that has a white colored genus Geotrichum sp. and on YEA medium obtained 2 isolates, black has the genus Aspergillus sp. and white can not be identified.
\end{abstract}

Keywords: bulb of bawang dayak, Eleutherine palmifolia, endophytic fungi, YEA, MEA

\begin{abstract}
ABSTRAK
Bawang dayak (Eleutherine palmifolia Merr.) merupakan salah satu tumbuhan endemik Kalimantan, yang secara empiris bagian umbinya telah digunakan dalam pengobatan degeneratif. Jamur endofit memainkan peran dalam produksi metabolit sekunder. Jamur endofit merupakan jamur yang dapat hidup pada bagian daun, batang maupun akar pada tumbuhan. Tujuan penelitian ini adalah mengisolasi jamur endofit yang terdapat pada umbi bawang dayak dan mengetahui karakteristiknya secara mikroskopik dan makroskopik. Isolasi jamur endofit dilakukan pada medium Yeast Extract Agar (YEA) dan Malt Extract Agar (MEA) dengan teknik sterilisasi permukaan menggunakan alkohol $70 \%$ dan $\mathrm{NaOCl} 1 \%$. Hasil isolasi jamur endofit pada medium MEA diperoleh 1 isolat berwana putih yang bergenus Geotrichum sp. dan pada medium YEA diperoleh 2 isolat berwarna hitam yang bergenus Aspergillus sp. dan berwarna putih.
\end{abstract}

Kata kunci $\quad$ : Bawang dayak Eleutherine palmifolia, jamur endofit, YEA, MEA

\section{Pendahuluan}

Bawang dayak (Eleutherine palmifolia (L.) Merr.) merupakan salah satu jenis tanaman yang memiliki khasiat bagi kesehatan. Di Indonesia tanaman ini banyak terdapat di daerah Kalimantan dan penduduk lokal Kalimantan telah lama menggunakan sebagai obat tradisional (Kuntorini, 2010). Pada umumnya bagian tanaman yang digunakan yaitu umbi 
dan daun. Tanaman bawang dayak memiliki manfaat sebagai antiradang, menghentikan pendarahan dan antitumor (Hidayah, 2015).

Mikroba endofit merupakan mikroorganisme yang tumbuh dalam jaringan tumbuhan. Mikroba endofit dapat diisolasi dari jaringan akar, batang dan daun, dan yang paling umum ditemukan adalah dari jenis fungi (Strobel, 2003). Beberapa tumbuhan dapat menurunkan senyawa bioaktif yang dikandungnya kepada jamur endofit yang tumbuh dalam jaringannya, sehingga jamur endofit tersebut dapat menghasilkan senyawa yang sama dengan inangnya (Prihatiningtias, 2007).

Menurut Tan \& Zou (2000), mikroba endofit memang dapat menghasilkan senyawa bioaktif yang karakternya mirip atau sama dengan inangnya. Hal ini disebabkan adanya pertukaran genetik yang terjadi antara inang dan mikroba endofit secara evolusioner.

Dengan demikian potensi ini dapat dikembangkan dengan isolasi jamur endofit, khususnya pada jaringan umbi bawang dayak yang mengandung berbagai senyawa metabolit sekunder yang beraktivitas sebagai antifungal, antiviral, antiparasitik dan antimikroba Oleh karena itu, dalam penelitian ini dilakukan isolasi dan karakterisasi jamur endofit yang ada pada umbi bawang dayak.

\section{METODE PENELITIAN}

\section{Bahan}

Bahan yang diteliti yaitu umbi bawang dayak (Eleutherine palmifolia). Untuk sterilisasi permukaan digunakan alkohol $70 \%$ dan $\mathrm{NaOCl} 1 \%$. Medium yang digunakan adalah Yeast Extract Agar (YEA) dan Malt Extract Agar (MEA), dimana masing-masing medium ditambahkan kloramfenikol. Bahan yang digunakan untuk uji mikroskopik yaitu gliserin, kertas saring dan methylene blue.

\footnotetext{
Alat

Peralatan yang digunakan dalam penelitian ini adalah timbangan analitik, autoklaf, inkubator, cawan petri, erlenmeyer, gelas kimia, spoit injeksi, hot plate, bisturi, Laminar Air Flow, mikroskop kamera dan alat penunjang lainnya.
} 


\section{Prosedur}

\section{a. Isolasi Jamur Endofit}

Teknik isolasi jamur endofit dilakukan dengan metode tanam langsung. Selama pengerjaan isolasi dilakukan di dalam LAF (Laminar Air Flow) dalam kondisi steril. Sampel umbi bawang dicuci dengan air mengalir terlebih dahulu. Selanjutnya dilakukan sterilisasi permukaan sampel dengan cara direndaman sampel dalam alkohol 70\% selama 2 menit, kemudian direndam dalam $\mathrm{NaOCl} 1 \%$ selama 5 menit dan dibilas menggunakan aquadest steril sebanyak 3 kali. Jaringan umbi dibuka dengan cara dilakukan pemotongan menggunakan pisau steril, dengan ukuran $\pm 1 \times 1 \mathrm{~cm}$. Masing-masing potongan sampel diletakkan pada permukaan medium YEAC (Yeast Extract Agar Chloramphenicol) dan medium MEAC (Malt Extract Agar Chloramphenicol) yang telah memadat dengan posisi bagian jaringan umbi menempel pada medium, dalam satu cawan petri berisi 3 potongan sampel. Diinkubasi selama $7-14$ hari pada suhu $25^{\circ} \mathrm{C}$.

\section{b. Pemurnian jamur endofit}

Pemurnian dilakukan untuk memisahkan koloni jamur endofit hingga diperoleh isolat jamur endofit. Koloni jamur yang tumbuh di sekeliling sampel umbi bawang dayak dimurnikan berdasarkan morfologi makroskopik yang dapat diamati dari warna serta pertumbuhan koloni jamur. Masing-masing isolat jamur endofit yang diperoleh, kemudian dipindahkan menggunakan pencadang ke dalam media YEAC dan MEAC pada cawan petri untuk memisahkan koloni endofit dengan morfologi berbeda untuk dijadikan isolat tersendiri.. Diinkubasi selama 5-7 hari pada suhu $25{ }^{\circ} \mathrm{C}$, jika pada saat pengamatan ditemukan pertumbuhan koloni yang berbeda secara makroskopis maka dipisahkan kembali hingga diperoleh isolat murni.

\section{c. Karakterisasi isolat jamur endofit}

Karakterisasi isolat jamur endofit dengan melakukan pengamatan ciri-ciri makroskopik dan mikroskopik. Karakterisasi secara makroskopik ini dilakukan dengan pengamatan isolat jamur endofit yang telah murni meliputi warna, bentuk koloni, dan elevasi. Karakterisasi secara mikroskopik ini dilakukan pengamatan menggunakan preparat isolat jamur endofit melalui mikroskop. Terdapat dua jenis metode mikroskopik yaitu metode mikroskopik langsung. Metode mikroskopik langsung dilakukan dengan meneteskan methylen blue yang telah diinokulasikan isolat jamur endofit dan diamati menggunakan 
mikroskop. Sedangkan metode mikroskopik tidak langsung dilakukan dengan cara diinokulasikan isolat jamur endofit di atas medium YEA dan MEA yang ada di object glass dan dibuat dalam kondisi lembab dengan gliserin yang ditetesi pada kertas saring sebagai pelapis cawan petri, kemudian diinkubasi selama 5-7 hari pada suhu $25{ }^{\circ} \mathrm{C}$, selanjutnya diamati menggunakan mikroskop.

\section{HASIL DAN PEMBAHASAN}

\section{a. Isolasi Jamur Endofit}

Jenis isolat jamur endofit yang berbeda dapat berasal dari satu tanaman inang. Strobel dan Daisy (2003) memperkirakan paling tidak ada 1 sampai 4 jenis jamur yang hidup berasosiasi dengan tumbuhan sebagai jamur endofit. Isolasi jamur endofit terlebih dahulu dilakukan sterilisasi permukaan sampel yaitu umbi bawang dayak sebelum ditanamkan dalam medium. Sterilisasi permukaan sampel dilakukan untuk membunuh mikroba epifit atau mikroba yang menempel dibagian permukaan umbi, sehingga koloni yang tumbuh pada permukaan medium merupakan koloni jamur endofit dari umbi bawang dayak. Sterilisasi permukaan sampel dilakukan dengan cara merendam sampel dalam alkohol $70 \%$, dan $\mathrm{NaOCl} 1 \%$, proses pengerjaan tersebut dilakukan secara aseptis di dalam Laminar Air Flow (LAF). Penggunaan alkohol $70 \%$ untuk sterilisasi permukaan memiliki spektrum yang sempit, untuk itu perlu dikombinasikan dengan bahan kimia lainnya seperti natrium hipoklorit $(\mathrm{NaOCl})$. Umbi bawang dayak yang telah disterilisasi permukaanya kemudian dibuka jaringanya dan ditempelkan pada medium yang telah memadat. Medium yang digunakan saat isolasi yaitu YEA dan MEA yang masing-masing ditambahkan dengan kloramfenikol (YEAC) dan (MEAC), hal ini dilakukan untuk menekan pertumbuhan bakteri yang kemungkinan akan ikut tumbuh saat isolasi dilakukan. Jamur yang tumbuh di sekitar umbi bawang dayak dimurnikan hingga memperoleh isolat jamur endofit. Pemisahan ini berdasarkan warna dan pola pertumbuhan koloni jamur dan ditumbuhkan kembali dalam medium YEAC dan MEAC.

\section{b. Karakterisasi Jamur Endofit}

Karakterisasi yang dilakukan yaitu secara makroskopis dan mikroskopis terhadap isolat jamur endofit umbi bawang dayak. Hasil isolasi jamur endofit dapat dilihat pada gambar 1 


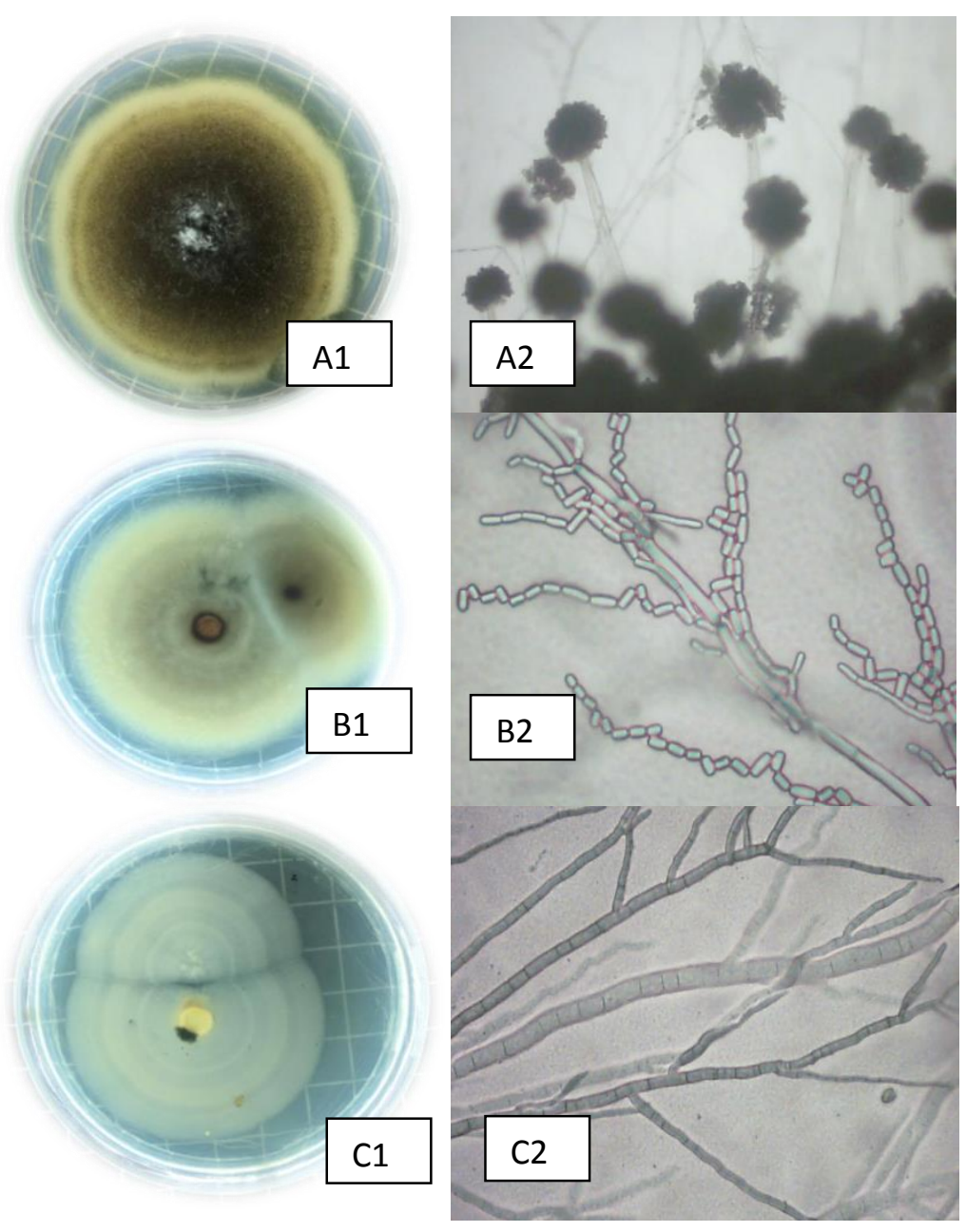

Gambar 1. Isolat jamur endofit umbi bawang dayak (Eleutherine palmifolia Merr.) Diperoleh tiga isolat jamur endofit, yaitu (A1) Isolat Jamur Endofit Hitam, (A2) hasil pengamatan mikroskopik isolat jamur endofit hitam, (B1) Isolat jamur endofit putih, (B2) Hasil pengamatan mikroskopik isolat jamur endofit putih, (C1) Isolat jamur endofit putih, dan (C2) Hasil pengamatan mikroskopik isolat jamur endofit putih.

Isolasi jamur endofit umbi bawang dayak yang diperoleh yaitu 3 isolat jamur. Secara makroskopis dapat dilihat bahwa jamur endofit A1 berwarna hitam dengan tepi berwarna putih, memiliki bentuk circular, elevasi flat serta memiliki permukaan yang konsentris. Secara mikroskopis isolat jamur A2 memiliki sporangium berbentuk bulat dan memiliki hifa asepta. Pengamatan jamur secara mikroskopis dibandingkan dengan literatur illustrated Genera of Imperfect Fungi, jamur endofit A1 merupakan genus dari aspergillus sp. Aspergillus sp telah banyak diisolasi sebagai endofit dan beberapa di antaranya memiliki aktivitas sebagai antimikroba, seperti yang diisolasi dari tumbuhan inang Andographis paniculata(Elfita et al., 2011) dan Garcinia mangostana (Elfina et al., 2014). Posangi (2014) 
melaporkan bahwa jamur Aspergillus sp. menunjukkan aktivitas antibakteri yang tinggi terhadap bakteri E. coli yang merupakan bakteri Gram negatif. Hal ini diperkuat oleh pernyataan Singh dan Bharate (2005) bahwa secara umum senyawa antimikroba yang dihasilkan oleh Aspergillus bersifat netral, polar, dan memiliki gugus fenol. Fenol ini mampu mendenaturasikan protein pada dinding dan membran sel bakteri dan fungi. Jamur Aspergillus sp pada media steril suhu kamar yaitu $25^{\circ} \mathrm{C}$ dalam 9 hari sudah mulai membentuk aflatoksin. Produksi aflatoksin ditentukan oleh macam karbohidrat dalam substrat dan alfaamilase yang diproduksi oleh A. flavus, maka pembentukan aflatoksin sangat ditentukan pula oleh faktor potensial genetik fungi dan lama kontak antara fungi dengan substrat (Purnamasari, 2016).

Isolat jamur endofit B1 secara makroskopis memiliki warna putih berbentuk circular dan memiliki elevasi flat serta permukaan yang halus. Secara mikroskopis jamur B2 memiliki konidia, konidiofor serta hifa bersepta. Dibandingkan dengan literatur illustrated Genera of Imperfect Fungi jamur B2 merupakan genus Geotrichum sp. Dimana fungi Geotrichum sp dapat menghasilkan senyawa antimalaria yang tumbuh pada tumbuhan Crassocephalum crepidioides (Strobel, 2003). Ekstrak kasar Geotrichum sp yang diisolasi dari Crassocephalum crepidioides ditemukan menjadi aktif terhadap Plasmodium falciparum dan senyawa baru 3-dihydroisocoumarins (Kongsaeree, 2003).

Pada isolat jamur endofit $\mathrm{C} 1$ dilihat secara makroskopis memiliki warna putih dan bentuk circular. Isolat jamur endofit $\mathrm{C} 1$ juga memiliki elvasi flat serta permukaan yang konsentris. Secara mikroskopik isolat jamur endofit C2 memilki hifa bersepta/ memiliki sekat namun spora/ konidia tidak dapat terlihat sehingga genus isolate jamur endofit $\mathrm{C} 2$ tidak dapat diketahui.

\section{KESIMPULAN}

Hasil isolasi jamur endofit dari umbi bawang dayak (Eleutherine palmifolia Merr.) diperoleh tiga isolat jamur endofit, diduga dua diantaranya merupakan jamur dengan genus Aspergillus sp. dan Geotrichum sp.

\section{DAFTAR PUSTAKA}

Elfina, D., Martina, A., Roza, R.M. 2014. Isolasi dan karakterisasi fungi endofit dari kulit buah manggis (Garcinia mangostana L) sebagai antimikroba terhadap Candida albicans, Staphylococcus aureus dan Escherichia coli. J. Online Mahasiswa Bidang MIPA, 1:1-10.

Elfita, Muharni., dkk. 2011. Senyawa antimalaria dari jamur endofitik tumbuhan sambiloto (Andographis paniculata Nees). J. Nature Indonesia 13:123-129. 
Hidayah, Anita Sarah., dkk. 2015. Uji Antioksidan Umbi Bawang Dayak (Eleutherine bulbosa Merr.). Prosiding Penelitian SPeSIA Unisba ISSN 2460-6472.

Kongsaeree, Palangpon and Samran Prabpai. 2003. Antimalarial Dihydroisocoumarins Produced by Geotrichum sp., an Endophytic Fungus of Crassocephalum crepidioides. American Chemical Society and American Society of Pharmacognosy

Posangi, Jimmy dan Robert A. Bara. 2014. Analisis Aktivitas Dari Jamur Endofit Yang Terdapat Dalam Tumbuhan Bakau Avicennia Marina Di Tasik Ria Minahasa. Jurnal Pesisir dan Laut Tropis Volume 1 Nomor 1.

Prihatiningtias W. 2007. Prospek mikroba endofit sebagai sumber senyawa bioaktif. Majalah Obat Tradisional 12 (42)

Purnamasari, Listya., dkk. 2016. Kajian Produksi Aflatoksin B1 Kasar Dari Isolat Kapang Aspergillus flavus Lokal Pada Media Jagung dan Jangung+Kacang Tanah. Buletin Peternakan Vol. 40 (2) : 133-137, ISSN-0126-4400 E-ISSN-2407-876X

Singh IP, Bharate SB. 2005. Anti-HIV Natural Products. Journal Current Science. 89: 269290.

Strobel, G.A. 2003. Endophytes as sources of bioactive products. pp.11

Strobel, G. A., and B. Daisy. 2003. Bioprospecting for Microbial Endhophytes and Their Natural Products. Microbiology and Molecular Biology Review. 67. (4). 419-502.

Tan, R.X., and W.X. Zou. 2001. Endophytes : a rich source of functional metabolites. Nat. Prod. Rep. 18: 448-459. 